\title{
Saving seeds: The Svalbard Global Seed Vault, Native American seed savers, and problems of property
}

\author{
Sheryl D. Breen* \\ University of Minnesota, Morris
}

Submitted September 1, 2014 / Revised March 11, 2015 / Accepted March 15, 2015 /

Published online March 19, 2015

Citation: Breen, S. D. (2015). Saving seeds: The Svalbard Global Seed Vault, Native American seed savers, and problems of property. Journal of Agriculture, Food Systems, and Community Development, 5(2), 39-52.

http://dx.doi.org/10.5304/jafscd.2015.052.016

Copyright (C) 2015 by New Leaf Associates, Inc.

\begin{abstract}
This case study contrasts centralized ex situ conservation of food and crop plant genetic resources with many Native Americans' preference for informal, localized in situ conservation. First, I examine ex situ genebanks operated by governments and research institutions, with particular attention to the Svalbard Global Seed Vault built into the mountainous permafrost on a Norwegian island in the High Arctic. Second, I describe Native American seed-saving efforts in the United States, drawing primarily on projects to preserve culturally

* Sheryl D. Breen, assistant professor, Division of Social Science, University of Minnesota, Morris; $600 \mathrm{E} 4^{\text {th }}$ Street; Morris, Minnesota 56267 USA; breens@morris.umn.edu

\section{Note}

Portions of this manuscript were presented at the 2014 Western Political Science Association Annual Meeting, the 2014 University of Vermont Food Systems Summit, and the 2014 American Political Science Association Annual Meeting. This research was supported by a grant-in-aid from the University of Minnesota.
\end{abstract}

significant seeds and promote food sovereignty at the local or tribal level. In general, Native American projects focus on the integration of cultural heritage and food independence through understandings of seeds as a tribal commons. Through these contrasting cases - the Svalbard vault and localized Native American seed-saving projectsI analyze the ways in which divergent understandings of "seedness" and seed ownership are crucial elements in discussions of seeds as property. In conclusion, I point out that the Svalbard Global Seed Vault is unique in its potential ability to cross the political and cultural divide over the ownership and conservation of seeds and thereby promote the vital ecological need for both ex situ and in situ seed preservation. Furthermore, I argue that recognition of the divergent understandings of "seedness" provides a useful way of examining the complementarity and limitations of specific models of in situ and ex situ seed conservation and, more broadly, the future of farmers' rights to the genetic heritage developed over generations in the fields. 


\section{Keywords}

agriculture, genebanks, Native Americans, property, seeds

\section{Introduction}

Seeds are the essence of life. Without their varied yields, the earth would lack agriculture, livestock, food systems, and ecological stability. In all shapes, sizes, and distributions, seeds are genetic powerhouses that store life's codes. Nonetheless, mounting evidence demonstrates an erosion in the seed biodiversity that is necessary for viable food systems (Food and Agriculture Organization of the United Nations [FAO], 2010, 2013). Some seed varieties have been unable to adapt as habitats change or shrink, noncommercial seed-saving techniques have disappeared along with community elders, and a relatively small number of hybrid and transgenic commodity crop varieties-none of which yields seeds that can be saved for plantingdominate global agriculture. Meanwhile, the botanical populations of historic landraces (the historic localized varieties that exhibit far higher levels of variation than the modern named, uniform cultivars [Fowler \& Mooney, 1990) and their wild cousins continue to decline (Kastler, Onorati, \& Brac, 2013; Nazarea, Rhoades, \& Andrews-Swann, 2013). War and social unrest have decimated seed banks in Afghanistan, and unique local varieties are at risk of permanent loss in other food systems (Cardinale et al., 2012; FAO, 2010; C. Gardner, personal communication, September 22, 2013).

A number of seed-saving projects from local to international levels work to slow this loss of seed biodiversity, alleviate environmental and health concerns, and proactively respond to climate change by protecting heritage food and agriculture varieties. One such project is the Svalbard Global Seed Vault, a centralized storage facility built into the mountainous permafrost on a Norwegian island in the High Arctic. At the same time, traditional seed-saving practices are regaining ground in recent years, and small seed libraries of openpollinated varieties are springing up around the United States, as indicated by the growing list monitored by the Seed Library Social Network (http://seedlibraries.org). At the international level, indigenous and peasant movements such as $\mathrm{La} \mathrm{Via}$
Campesina (http://www.viacampesina.org) promote seed-saving and use of traditional seed varieties, citing political and cultural as well as ecological reasons.

At the same time, however, the rise of hybrid seed lines throughout the $20^{\text {th }}$ century and the more recent commercial development of genetically modified varieties mean that many farmers choose from an increasingly limited catalog. Patented or licensed seed varieties must be purchased anew each growing season rather than produced and saved by growers. These changes in the availability and ownership of agricultural seeds can have significant ecological, political, and cultural consequences (Aoki, 2008). Both scholars and food sovereignty activists have characterized the increasing dominance of proprietary seeds as a trend that dampens local efforts to save seed, maintain diverse food crops, and control agricultural production (Barker, Freese, \& Kimbrell, 2013; Kastler et al., 2013; Pechlaner, 2012; Shiva, Lockhart, \& Shroff, 2013). Some contend that plant breeding has shifted dramatically from community knowledge shared across generations to a privatized system dominated by a few seed monopolies (e.g., Barker, Freese, \& Kimbrell, 2013, p. 9) and warn that this trend leads to a more centralized and vertically integrated seed economy (McIntyre, Herren, Wakhungu, \& Watson, 2009; Shiva, Shroff, \& Lockhart, 2012). In addition, critics of the shift toward seed privatization argue that plant genetic resources must remain part of a common heritage, questioning the dominant approach to the creation and maintenance of property rights. In accordance with 17th century English political theorist John Locke's labor theory of value, which has provided the foundation for understandings of property in liberal democracies (Tully, 1980), legal stipulations at both national and international levels hold that research and development on crop variety traits add human-created value and thus secure the legal right to ownership of seed genetics in the form of intellectual property rights (Shiffrin, 2001).

The most significant international document on this issue, the International Treaty on Plant Genetic Resources for Food and Agriculture (ITPGRFA), was implemented in 2004 (Pant \& Ramisch, 2010) and took shape amid concerns 
about the trend toward corporate intellectual property rights, particularly on the part of negotiators from developing states. Negotiations on the ITPGRFA elicited difficult debates on the political problems of seeds as property and yielded provisions of particular importance to continuing issues of seed ownership. For example, the treaty addresses farmers' access to seed varieties through their right to save, use, exchange, and sell their own seed as well as communities' rights to share in the benefits of seed research based on indigenous germplasm (Cooper, 2002; Correa, 2003; Coupe \& Lewins, 2007; Helfer, 2003; Senior, 2004). More than a decade after implementation, these treaty provisions continue to evolve in terms of publicpolicy structure (Andersen \& Winge, 2013; Brush, 2007; Nazarea et al., 2013).

In addition to explicit policy debates, the political problems of seeds as property also arise from a subtler source that involves divergent understandings of the meaning and identity of the seeds themselves. Scientific research that is dedicated to preserving genetic resources, improving its productivity, and developing new varieties tends to approach seeds as discrete material objects-in essence, as active storage containers of genetic material. From this perspective, empirical knowledge is gained through ex situ conservation and controlled experimentation in research plots outside of the plants' natural habitat. The fact that farmers cannot save usable seeds for replanting from their hybrid and transgenic crops is balanced by the advantages of new productive efficiencies and disease and pest resistances gained from plant breeding (Fedoroff, 2010). In contrast, however, many global indigenous groups view seeds as responsive beings that are inherently embedded within ecological and spiritual webs of kinship. According to this perspective, knowledge is relational and narrative and is gained through in situ community-based care and cultivation (Booth, 2003; Brascoupé, 2002). Saving seed is seen as an inherent part of the cycle of farming, and seeds saved for the next year's crop are an essential part of a community's wealth (Nelson, 2008; G. L. Wilson, 1987). In this sense, the very notion of what it means to be a seed can lead to different understandings of whether in situ or ex situ conser- vation is necessary and whether seeds should be legally and politically defined as objects of property.

To probe these divergent perspectives on seedsaving and seeds as property, this case study is part of a larger project in which I examine recent shifts in the collection, protection, and possession of plant genetic resources and the ways in which these changes reflect divergent understandings of seeds as property in an increasingly globalized system. As a component of that project, this case study contrasts scientific and/or technological approaches to ex situ conservation of food and crop genetic resources with many Native Americans' preference for informal, localized in situ conservation. To do so, I first examine the role of ex situ genebanks, with particular attention to the Svalbard Global Seed Vault. Second, I describe some of the Native American seed-saving efforts in the U.S., drawing primarily on projects to preserve heritage and culturally significant seeds and to devise food sovereignty policies at the local or tribal level. Through these contrasting cases - the Svalbard vault and localized Native American seed-saving projects-I examine the ways that divergent understandings of "seedness" and seed ownership are crucial elements in the political problem of seeds as property. In conclusion, I point out that the Svalbard Global Seed Vault is unique among ex situ facilities in its potential ability to cross the political and cultural divide regarding ownership, and I suggest that the Svalbard vault is particularly well positioned to promote the vital ecological need for both ex situ and in situ conservation. Furthermore, I argue that recognition of the divergent understandings of "seedness" provide a useful way of thinking about the complementarity and limitations of specific models of in situ and ex situ conservation and, more broadly, the future of farmers' rights to the genetic heritage developed in situ over generations.

In terms of methodological approach, this case study is a political project that is rooted in the subfields of normative political theory and the history of political thought regarding property. In addition, this study highlights an empirical element based on long-form personal interviews and personal experience. This integration of philosophical and empirical work echoes a point made by political theorist Iris Marion Young, who argued that the distinction 
between normative and empirical statements does not lead to separate methodologies. Just as normative theory must be grounded in empirical inquiry, she wrote, any empirical study inherently includes normative research judgments (Young, 2011). Likewise, in the case of this project, the political problems of seeds as property must involve an integrated approach. To accomplish this task, this case study's theoretical analysis draws on empirical work associated with (1) research visits and interviews at the Svalbard Global Seed Vault, the U.S. Department of Agriculture's National Center for Genetic Resource Preservation in Fort Collins, Colorado, and the USDA North Central Regional Plant Introduction Station in Ames, Iowa; (2) research visits and interviews I conducted with leaders of Native American seed-saving projects in the Cherokee Nation, Tesuque, Taos, and Zuni Pueblos, Navajo Nation, and Tohono O'odham Nation ${ }^{1}$; and (3) a curricular development project on Anishinaabeg farming and gardening conducted by the University of Minnesota, Morris, in partnership with the White Earth Land Recovery Project, in which I served as co-investigator.

\section{The Svalbard Global Seed Vault: $E_{x}$ Situ Conservation}

Amateur plant breeders have modified seeds and altered genetic resources since the dawn of agriculture 10,000 years ago. Likewise, growers have saved seeds and used seed caches in caves and other cool, dark locations for many centuries to protect landraces. The wealth of food and agricultural genetic resources is not equally spread around the world, however, and today's less developed nations in the global South are home to most of the gene-rich biodiversity hotspots. The industrialized and colonizing global North, in contrast, has been relatively gene-poor, an imbalance that the Columbian Exchange attempted to eradicate via expeditions and colonization beginning in the $15^{\text {th }}$ century (Crosby, 1972). This acquisition process is one that persistently (although not exclusively)

\footnotetext{
${ }^{1}$ The University of Minnesota Institutional Review Board categorized this element of the project as interviews of recognized experts rather than generalizable research of human subjects and therefore deemed it was exempt from IRB review.
}

involved exploitation and theft and which critics within the food sovereignty movement describe as biopiracy, meaning the fraudulent acquisition of ownership over genetic materials (Brush, 2002; Mgbeoji, 2006; Mushita \& Thompson, 2007; Robinson, 2010; Shiva, 1997). Historically, plant specimens and their genetic material were brought to botanical garden collections in the North and were also propagated as privatized commercial enterprises through research stations and highoutput production plantations in colonized regions of the South, a competitive design that could cause economic collapse when the originating areas were deprived of markets (Fowler \& Mooney, 1990; Kloppenburg, 2005; Mann, 2011).

In addition to botanical gardens and research stations, ex situ gene depositories first arose in the 1920s, in large part due to the leadership of Soviet geneticist and botanist Nikolai Vavilov, one of the premier figures in the modern history of seed collections. With the needs of crop breeding in mind, Vavilov began the systematic collection and centralized propagation of seeds and plant tissue samples, thus instituting ex situ depositories as an intrinsic part of agricultural research and development. The Vavilov All-Russian Scientific Research Institute of Plant Industry remains one of the four largest national genebank collections in the world, along with the United States' National Plant Germplasm System, the National Bureau of Plant Genetic Resources in India, and the Institute of Crop Germplasm Resources in China (Harlan, 1995; Westengen, Jeppson, \& Guarino, 2013). The immense size of these collections means that although farmers' fields in the global South have provided the original materials for the world's contemporary genebanks, the growth and cataloging of ex situ collections in the global North through acquisition, research development, and propagation has been so extensive that they now are the main source of genetic resources for plant breeding and research. In contrast, the more fragile in situ fields and gardens are prone to deterioration or complete loss due to economic, political, technical, and/or climatic instability. Rather than make expeditions to the centers of diversity, as was done earlier, plant breeders now turn to the genebanks' extensively documented collections of wild varieties, 
landraces, and developed cultivars (Fowler, Smale, \& Gaiji, 2001), and genetic engineering has turned seed companies' attention to the genes rather than the plants themselves (Kastler et al., 2013). Field research for acquisition and cataloging has not ended, by any means, but ex situ genebanks have assumed crucial importance in the contemporary world of biodiversity preservation and plant breeding, along with pharmaceutical and food system research, all of which hold significant economic implications.

One of the newest of the ex situ collections is the Svalbard Global Seed Vault, an architecturally innovative storage facility bored into the permafrost of a High Arctic island. The vault is located on Spitsbergen, the only island in the Svalbard archipelago that is permanently inhabited and has a human population of fewer than 2,500 (and a polar bear population of nearly 3,000 , according to residents). Svalbard is under Norwegian sovereignty but subject to international law according to the 1920 Spitsbergen Treaty (Grydehøj, Grydehøj, \& Ackrén, 2012). The government of Norway owns the Svalbard vault, the multinational Nordic Genetic Resource Center (NordGen) manages the vault's deposits and database under the direction of the Nordic Council of Ministers, and the Global Crop Diversity Trust (GCDT), a nongovernmental organization with an international board of directors, provides operating funds and works with seed deposits (C. Fowler, personal communication, February 25, 2014; GCDT, n.d.; Government of Norway, n.d.; R. Von Bothmer, personal communication, February 25, 2014). Prior to passage of the ITPGRFA in 2004, disputes among developing countries, industrialized nations, and the commercial seed industry over access and control of the seeds had hindered proposals to construct a global seed vault at various locations for more than two decades. With the new treaty in place, Norway's history of political non-alignment, economic stability, and environmental preservation, in addition to its geological suitability and willingness to pay construction costs, made a vault project politically possible under international governance (Coupe \& Lewins, 2007; C. Fowler, personal communication, February 25, 2014).

The vault, which opened in 2008, has three vaults with the capacity to store 4.5 million seed samples. Assuming an average size of 500 seeds per sample, the vaults allow a maximum of 2.25 billion seeds, enough to hold duplicates of the 1.5 million unique seed samples now held in seed banks worldwide (Fowler, 2008). The Svalbard vault currently holds 820,000 samples from 53 genebanks and includes more than a third of the accessions of 156 crop genera stored as seeds in global genebanks (R. Von Bothmer, personal communication, February 25, 2014; Westengen et al., 2013). Most of the samples in the Svalbard vault are no longer found in the field, and its geological location and infrastructure means that it faces no foreseeable threats from rising sea level or melting permafrost (C. Fowler, personal communication, February 25, 2014).

Significantly, the Svalbard Global Seed Vault is distinct from all other centralized depositories in a crucial sense. Unlike research-oriented genebanks that are focused on current plant breeding developments, the Svalbard vault operates solely as a backup ex situ conservation facility to preserve food and crop genetic resources for the next 10,000 years (Fowler, 2008). Governments, research institutions, and organizations can deposit seed samples in the Svalbard vault, but in each case the depositor's national government must authorize the act through an extensive agreement in accordance with the ITPGRFA's placement of seed sovereignty at the national level (R. Von Bothmer, personal communication, February 25, 2014; FAO, 2009). The seeds are marked and permanently stored within the vaults, which are cooled to 0 degrees F, approximately 25 degrees colder than the location's average permafrost temperature. Unless the depositor chooses to reclaim the container for plant grow-outs to refurbish viable seed, the container sits untouched and can be accessed only by the depositor. This contractual arrangement is a so-called "black box" agreement designed to guarantee that depositors, through their national governments, maintain control and sole ownership of the seeds. The vault does not include research facilities, its governing bodies have no subsidiary contracts with research institutions, and its High Arctic location does not allow for propagation. As stated by Cary Fowler, the retired executive direc- 
tor of the Global Crop Diversity Trust who drafted the original plan for the vault and oversaw its approval, construction, and operation, "This is not the place for anything but conservation" (C.

Fowler, personal communication, February 25, 2014).

The vault's unique mission and design are significant for questions of food sustainability, food resilience, and food sovereignty. By storing seeds in a low-tech permafrost environment that is internationally governed, politically stable, and logistically feasible, and by excluding research activities in favor of a 10,000-year vision focused on seed preservation, the vault affords a high probability that germplasm will survive anticipated bottlenecks of diversity depletion (E. O. Wilson, 2002) and be accessible if or when the germplasm is needed. The vault is, in a sense, the ultimate backup collection, ensuring the most secure "black box" arrangement that is currently possible under international law and providing the widest degree of sample diversity for food and crop sustainability.

\section{Native American Seed Savers: In Situ Conservation}

Although they clearly share strong concerns about the preservation of seed biodiversity, many Native American seed savers are unwilling to join the move toward ex situ seed depositories and reject the ITPGRFA's placement of seed sovereignty at the national level. Overall, my research with Native American seed-saving activists and programs revealed persistent skepticism of centralized ex situ depositories and indicates that this skepticism is more than a tactical disagreement. Not surprisingly, counterarguments made by Native seed savers point to historical precedents of government deception and greed and, as described below, they describe community-based in situ alternatives that they believe will maintain local control and seed viability, in contrast with national ex situ approaches. Interviews with researchers at U.S. Department of Agriculture (USDA) depositories confirmed this reluctance to participate in genebanks, as the scientists voiced concerns about the need for greater participation from tribal communities in the face of threats to in situ seed preservation from climate change and inadequate storage facilities.

Before examining perspectives from Native American communities and seed savers toward $e x$ situ genebanks, it is important to stress that neither Native Americans nor indigenous communities more broadly are monolithic in their views, despite some common patterns. Not only are indigenous groups disparate in environment, culture, and history, but also individuals within those groups are distinct in terms of political and cultural identification and personal experiences. While this case study addresses patterns of Native American responses to ex situ genebanks, it does not and cannot present a unitary Native American perspective.

With that cautionary note, the pattern that stands out during research interviews is one of skepticism toward participation in centralized seed depositories and a preference for relying on local alternatives. Despite plant-breeding researchers' long-standing pleas for tribal contributions to genebanks and despite evidence of the various ecological, economic, and political threats that constitute the case for ex situ depositories, I have found little support for participation. Information collected with the assistance and cooperation of Native American seed savers and tribal food sovereignty activists strongly supports the conclusion that these individuals and groups are deeply dedicated to the preservation of plant biodiversity and that their reluctance or refusal to make deposits to genebanks is not an indication of ecological ignorance or apathy. On the contrary, as they point out, Native American seed savers and food sovereignty activists have historical and political grounds for their skepticism regarding ex situ genebanks operated by government institutions for preservation of seed genetics. Native American seed savers whom I interviewed repeatedly expressed the conviction that the national government and its research institutions are the last parties that should be entrusted with the protection of tribal heritage seeds.

Likewise, skepticism toward ex situ genebanks is not a rejection of seed saving; the essential role of seeds in traditional farming is a persistent theme in the study of Native American farmers (Mt. Pleasant, 2011; Nabhan, 2002; G. L. Wilson, 1987), as is the importance of seed cultivation and devel- 
opment within indigenous cultures as a means to food sovereignty (LaDuke \& Alexander, n.d.; Nabhan, 1997, 2002; Ross, Sherman, Snodgrass, Delcore, \& Sherman, 2011; G. L. Wilson, 1987). In one relevant example, concerns about the role of traditional seeds drove the Anishinaabeg farming and gardening course jointly developed by the University of Minnesota, Morris (UMM), and the White Earth Land Recovery Project (WELRP) in 2012. This pilot project, which produced a summer course and curricular modules for adaptation by other institutions, sought to address the intersections of Anishinaabeg (Chippewa/Ojibway) food sovereignty with issues of culture, history, economics, and health. The course drew together students, University of Minnesota, Morris, faculty and staff, and Anishinaabeg elders and teachers under the leadership of principal investigators Winona LaDuke, an Anishinaabeg activist and founder of WELRP, and Sandra Olson-Loy, University of Minnesota, Morris, vice chancellor of student affairs. The course met for three immersion sessions throughout the 2012 growing season for class work and experiential learning at the Morris campus and the White Earth Reservation. The teaching team of University of Minnesota, Morris, faculty and staff and the enrolled students included both non-Native and Native members from several tribal nations. In sessions that focused on planting, midsummer, and harvest, the course highlighted gardening, harvesting, cooking, and learning from members of the White Earth Nation and at the campus Native American garden, with a consistent emphasis on the importance of heritage seeds. In addition to botany, history, and nutrition, the curriculum included discussions of colonialism, property theory, and seed sovereignty.

In a second example, the Tesuque Pueblo community farm project in northern New Mexico also stresses the importance accorded to community seed saving. Under the leadership of Emigdio Ballon, a plant geneticist from the Bolivian Quechua community, pueblo members reclaimed a section of floodplain for a small but intensive agricultural project that has received grants from private foundations such as the Christensen Fund to build an irrigation system, greenhouses, and a new seed-storage building and workshop. The pro- ject uses heritage seeds from pueblo elders and concentrates on teaching the youth of the community about food, nutrition, and pueblo heritage as they stabilize the community's seed library. The Tesuque Pueblo also sponsors an annual conference with the Traditional Native American Farming Association that draws Native seed savers and ranchers from a large area of the Southwest (E. Ballon, personal communication, July 31, 2013; C. Brascoupé, July 29, 2013; L. Hena, personal communication, July 29, 2013).

While both the Anishinaabeg curriculum and Tesuque Pueblo farming operation are directed toward reclaiming and preserving seeds at the local level, the Cherokee Nation, based in Oklahoma, provides a third example of following a different model in its approach to seed heritage and sovereignty. A garden dedicated to seed production near the tribal administrative headquarters in Tahlequah, Oklahoma, includes food and tobacco varieties associated with the tribe's history. The seeds are saved, sorted, bagged, and labeled, and each fall the Cherokee Nation president gives a bag of seeds to any registered member, a ceremony tied to the traditions of the Cherokee gift economy. Because the tribe's membership rules are relatively open, Cherokee members constitute the nation's second largest tribal group (second to the Navajo Nation), and the membership list extends broadly across the United States. As a result, at the same time that the seeds are viewed as a common heritage, the annual ceremony of sharing has raised internal questions about the implications of such wide geographic distribution and resulting access to commercial seed companies. In effect, the Cherokee gift economy is coming into tension with the tribe's contrasting need to maintain sovereignty over its heritage seeds. A group of tribal elders is working to resolve this tension by formulating a seed policy that will clarify access and control (P. Gwin, personal communication, July 25, 2013).

These examples, and others, lead to consideration of the political problems associated with seed ownership. In a discussion of seeds as property, it is important to remember that seeds currently being used for commercial food and crop production originated, either directly or indirectly, from the heritage seeds grown and selected by peasant 
farmers around the world. In accordance with that fact, in all three of the examples described above, Native American growers and seed savers stated their concerns that centralized ex situ collection of those seeds' genetics would constitute a confiscation of their cultural heritage and denial of their collective rights to use, exchange, and sell their seeds (also see Kastler et al., 2013, p. 48). When I asked whether they had considered depositing duplicates of their seeds into one of the U.S. depositories, such as the National Center for Genetic Resource Preservation, the Native farmers I interviewed repeatedly drew parallels between participation in genebanks and loss of control, equating public seed depositories and seed corporations' privatized collections and the resulting loss of access through Plant Breeders' Rights (PBR), seed patents, and contract law governing growers (see Aoki, 2008). Genebank administrators' and researchers' assurances that seed deposits can be made within a black-box arrangement appear to be unconvincing. "Money opens black boxes," said Clayton Brascoupé, program director of the Traditional Native American Farmers Association, expressing a commonly stated skepticism about the trustworthiness of black-box arrangements

(C. Brascoupé, personal communication, July 29, 2013). When seed corporations want germplasm, Brascoupé and others said, they will find a way to get it from the public depositories, regardless of contract stipulations, citing historical examples of government duplicity and fraud to tribes. Depositing seeds into a centralized genebank, they contend, is directly linked to loss of ownership and access.

When asked about the in situ alternatives and whether centralized genebanks are a necessary response to the fragility of local storage and the threats of climate change, Native Americans whom I interviewed and with whom I have worked expressed confidence that traditional ways of local seed conservation are sufficient or superior to the centralized ex situ approach and pointed to anthropological evidence of seed caches that maintain viability for long periods. However, none of the Native American seed-saving projects I visited was currently using these long-term preservation techniques. Instead, in situ seed selection and conservation were focused on propagation, i.e., providing seed stocks for immediate planting, and distribution to other Native American growers with the goal of improving nutritional health and food sovereignty. Some projects in the Southwest, such as the San Xavier Cooperative Farm operated by the Tohono O'odham Nation, have informal relationships with Native Seeds/SEARCH, a nonprofit seed bank in Tucson, Arizona, that has collected, propagated, and redistributed indigenous seeds and others suited to the Southwest climate since 1983 using both ex situ and in situ methods (B. Dorman, personal communication, August 6, 2013; M. Kruse-Peeples, personal communication, August 6, 2013; C. Schlaefli, personal communication, August 7, 2013; E. Sofro, personal communication, August 7, 2013). At the farm level, however, Native seed savers repeatedly expressed confidence in their ability to ensure long-term backup of their selected seed varieties by planning for duplicates in multiple locations and sharing seed stocks with Native farmers in other communities and tribes, thus maintaining local collective control of the common genetic resources.

These reasons for skepticism of centralized depositories are consistent with Native American writings and other research accounts on indigenous agriculture and Native American attitudes toward government projects (e.g., Bartecchi, 2009; BellSheeter, 2004; Brascoupé, 2002; Deloria, 1995; LaDuke, 2005; Ross et al., 2011). However, during interviews some Native seed savers raised an additional conceptual objection regarding the meaning and identity of seeds that has received comparatively little attention. As stated by Louie Hena, a tribal elder of Tesuque Pueblo and one of the leaders of New Mexico pueblos' efforts to enact tribal and state seed sovereignty laws, the methods of long-term storage used by federal genebanks face ethical problems based on the essential nature of seeds. According to Hena, because seeds are living beings that exist within a web of relationships, they are connected to the human who plants the seed, the microbes that live in the soil alongside the seed, the soil itself, the harvester, and those who use and/or consume the plant. These relationships are reciprocal and constitutive, which means that both seeds and humans are entities formed by and simultaneously forming life's actions around them- 
selves. According to this perspective, humans must recognize and protect those relationships through prayers or other signs of respect and connection. In other words, said Hena, relationships are the essence of what it means to be a seed, and that web of connections is denied by the long-term storage techniques used in most ex situ genebanks. In particular, he said, the use of liquid nitrogen tanks to create cold temperatures that are artificially extreme is ethically indefensible because this method physically isolates the seeds in ways that fundamentally deny the nature of life. To put Hena's point another way, he believes that these kinds of genebanks negate the essence of "seedness." Seeds are alive within a perpetual and dynamic cycle of planting, growth, and harvest, and their isolation in genebanks-despite the scientific goal of preserving genetic resources-works in opposition to their needs, he believes. Hena's view was echoed in various ways during interviews by other Native farmers and seed savers; various writers also have described the reciprocal relationships between humans and their crops. As noted by Dennis Martinez, chair of the Indigenous Peoples' Restoration Network, "The elders say that if you don't take care of the plants and talk to them and relate to them, they get lonely and go away" (Martinez, 1998, p. 1).

At one level, this perspective on the identity of seeds highlights an understanding of nonhuman nature as a network of relationships built on mutual need and respect. This view is reciprocal, collectivist, and based on tradition, in contrast to the more dominant unidirectional, individualist, and legalistic understandings of nature as property. At a second level, a description of seeds and their requirements as living entities highlights an epistemological distinction-a significant theoretical gap-that addresses the political problems of seeds as property. In a discussion of seeds as genetic resources that should be collected and preserved, what counts as knowledge? Can a description of seeds as relationship-constituted beings be discounted as spirituality rather than science and therefore be excluded from the scientific discussions of biodiversity and germplasm preservation that rely on the definition of seeds as property (Bielawski, 2003)? Conversely, does the provisional and dynamic nature of local knowledge and embodied understanding of seeds undermine the scientific argument for ex situ collections as a way to maintain food and crop biodiversity (Briggs, Sharp, Yacoub, Hamed, \& Roe, 2007; Brush \& Stabinsky, 1996)? Or, more hopefully, as I will argue, does recognition of the divergent understandings of "seedness" provide a useful way of thinking about the complementarity and limitations of specific models of in situ and ex situ seed conservation and, more broadly, the future of farmers' rights to the genetic heritage developed over generations in the fields?

\section{Conclusion: The Problems of Property}

Issues of ownership are inherent in the discussion of food systems and the seeds that constitute their foundations. For this reason, seed sovereignty is an essential component of food sovereignty, for "those who cannot ensure through ownership or other forms of control that they will reap benefits from the resources cannot be expected to go to the expense of conserving them for the use and aggrandizement of others. Thus, the very existence of the resource which feeds humanity is tied to patterns and arrangements of ownership and control and how these affect the way in which the benefits of diversity are shared, or not" (Fowler, 1994, p. xv). If we do not address the problems of property as they relate to seeds and the genetic resources they contain, we cannot hope for a vigorous response to the imminent threats to genetic biodiversity and the narrowing of food and crop varieties. As indicated in the previous section, many Native Americans reject the legitimacy of the historical, ongoing, and potential loss of access to and collective control over tribal heritage seeds and are concerned that the solicited deposits in centralized ex situ genebanks will exacerbate that loss.

As part of this discussion, however, we first must explicitly recognize the legitimacy of deep concerns raised by the fragility of in situ conservation. As stated above, the Svalbard Global Seed Vault already holds nearly a million samples, more than half of which are no longer found in the field. Local seed collections and distributions are not inherently faulty; on the contrary, these community conservation projects are the lifelines of small 
sustainable farming and subsistence gardening. Nonetheless, even those collections that are not immediately threatened by war or the effects of climate change are frequently subject to the inadequacies of volunteer labor, poorly trained growers and harvesters, administrative changes, and insufficient and unstable financing. Any viable effort to conserve food and crop varieties that have been developed through centuries of agriculture must recognize the value of both ex situ and in situ programs to biodiversity conservation.

Second, in response to the well founded concerns of Native American seed savers, political understandings of germplasm as intellectual property and the application of this perspective to indigenous and heritage seeds must incorporate a recognition of local knowledge-a multifaceted and complex concept that requires considerable wrestling before it can be brought usefully into the dialogue (e.g., see Brush \& Stabinsky, 1996). When we speak of indigenous or, more accurately, local knowledge and its implications for intellectual property rights, whose knowledge do we mean? As noted earlier, Native Americans are not a uniform corporate body - there is no unitary "Native American position"- and the interests of one tribal Nation may either conflict or harmonize with those of another. With these cautions in mind, seed preservation and the role of centralized ex situ collections must proceed from the foundation of local knowledge as both legitimate and necessary.

Some scholars working in conservation and environmental management have proposed ways that local knowledge and the Western scientific method can be brought together for the purpose of ecological preservation (e.g., Lertzman, 2010; Menzies, 2006; O'Flaherty, Davidson-Hunt, \& Manseau, 2008). The understanding of "seedness" as constituted by relationships, I argue, provides an additional insight for dialogue, particularly in regard to ex situ genebanks and the problems of property. On the one hand, the financial and legal integration of genebanks with industrial plant breeding corporations poses significant difficulties for projects that seek to bring scientific and indigenous knowledge together, such as EcosystemBased Management (Lertzman, 2010). On the other hand, the Svalbard Global Seed Vault demonstrates that ex situ seed banks are not necessarily research-oriented or tied to plant-breeding corporations. In effect, the Svalbard vault provides the most dependable guarantee of a backup depository with a black-box arrangement that can be devised under current international law. Furthermore, the permafrost and low-technology refrigeration that hold the seeds in below-freezing temperatures are more akin to traditional seed caches than to liquid nitrogen tanks and may be less objectionable on ethical grounds to the reciprocal, collectivist understanding of seeds, particularly if the Global Crop Diversity Trust increases its efforts to integrate representatives of local knowledge into its decision-making. In this sense, the Svalbard Global Seed Vault in Norway offers a particularly promising avenue toward $e x$ situ deposits that can protect and enforce indigenous seed sovereignty and increase preservation of vital genetic resources for food and agriculture.

Analysis of the political problems of seeds as property also suggests directions for food and crop policy that would affect seed savers of all groups, not just Native Americans. First, because seed biodiversity and sustainable food systems need both in situ and ex situ conservation, financial support and training are essential. Funding for in situ seed projects can easily fluctuate due to the economic and political (in)stability of individuals, communities, and nonprofit organizations, and localized projects rarely have access to or funding for adequate technology that ensures long-term conservation of viable seeds. In addition, while centralized depositories use low-temperature vaults and liquid nitrogen tanks, in situ seed libraries and collections often must rely on cardboard boxes or household refrigerators or freezers that can lead to rapid declines in seed viability. Furthermore, despite recent improvements in educational materials for amateur growers and seed savers, many seed savers lack scientific knowledge, leading to unintentional cross-pollination, poor germination rates, absent or incorrect documentation, and the potential loss of important genetic resources. This problem is particularly acute for local seed libraries that allow or expect seed recipients to make replenishing contributions from their home gardens. In addition, even the most carefully administered in 
situ seed projects can be abandoned or destroyed in times of political unrest. Centralized genebanks are not immune from such dangers, of course, but have been more secure due to professional and political institutionalization. One policy direction, therefore, is to counter the fragility of in situ alternatives through funding for seed-saving projects and education on seed-saving techniques at the community level. In return, community seed savers, including those involved in tribal projects, can share their expertise with other farmers and gardeners as well as plant breeders and researchers. Such an approach recognizes the multidimensional aspects of shared knowledge.

Second, the analysis suggests the importance of further revision and development of property law at the national and international levels. At the national level in the United States, intellectual property law and resulting court rulings have encouraged the seed industry's hybrid and transgenic domination and helped reduce Native and non-Native access to open-pollinated heritage seeds (Kloppenburg, 2005; Mascarenhas \& Busch, 2006). The open-source model launched in 2014 by the Open Source Seed Initiative (http://osseeds. org/) is an innovative alternative but may not find favor among tribal seed savers. The agreement at the core of the open-source model prevents privatization of seed genetics (although it does not prohibit commercialization), but in doing so it deliberately casts any open-source seed into the shared world of unrestricted access. Like the Cherokee seed giveaway described above, this approach may not resolve Native American seed savers' concerns about loss of a tribal heritage that is partially defined by a distinctive set of seed varieties.

At the international level, activists for increased seed sovereignty argue that the FAO must move to strengthen farmers' rights, access, and benefit-sharing of proceeds from food and crop genetic resources. As stated above, strong demands from less developed member nations of the FAO ensured that the treaty implemented in 2004 included components on these issues. Sovereignty remains at the national rather than community or regional level, which continues to concern Native American and other indigenous and peasant communities, and the FAO has interpreted its responsibility to share benefits by soliciting proposals for competitive investment.

At the same time, recognition and implementation of farmers' rights have moved forward in localized projects and yielded success stories (Andersen \& Winge, 2013), emphasizing the ongoing tension in international law in response to pressures for intellectual property rights. Further work can include considerations of sovereignty at the subnational level in addition to clarification and implementation of the ITPGRFA's access and benefit-sharing provisions.

\section{Acknowledgements}

The author is grateful for the help provided on this project by undergraduate research assistants Naomi Wente, Allison Wolf, Marcy Prince, and Jayce Koester. She also is grateful to the seed savers and scientists who generously granted interviews and provided tours of gardens, farms, and seed depositories in the United States and Norway.

\section{References}

Andersen, R., \& Winge, T. (2013). Realising farmers' rights to crop genetic resources: Success stories and best practices. Abingdon, UK: Routledge.

Aoki, K. (2008). Seed wars: Controversies and cases on plant genetic resources and intellectual property. Durham, North Carolina: Carolina Academic Press.

Barker, D., Freese, B., \& Kimbrell, G. (2013). Seed giants vs. U.S. farmers. Washington, D.C.: Center for Food Safety and Save Our Seeds. Retrieved from the Center for Food Safety website: http://www.centerforfoodsafety.org/reports/1770 Lseed-giants-vs-us-farmers\#

Bartecchi, D. (2009, November 4). USD A misrepresents situation of Native American farmers [Press release]. Fort Collins, Colorado: Village Earth. Retrieved from http://www.villageearth.org/pages/globalaffiliate-network/projects-pineridge-reservation/ usda-misrepresents-situation-of-native-americanfarmers

Bell-Sheeter, A. (2004). Food sovereignty assessment tool. Fredericksburg, Virginia: First Nations Development Institute. Retrieved from http://www.indigenousfoodsystems.org/content/ first-nations-development-institute-foodsovereignty-assessment-tool 
Bielawski, E. (2003). "Nature doesn't come as clean as we can think it": Dene, Inuit, scientists, nature and environment in the Canadian North. In H. Selin (Ed.), Nature across cultures: Views of nature and the environment in non-Western cultures (pp. 311-328). Dordrecht, the Netherlands: Kluwer Academic.

Booth, A. L. (2003). We are the land: Native American views of nature. In H. Selin (Ed.), Nature across cultures: Views of nature and the environment in nonWestern cultures (pp. 329-349). Dordrecht, the Netherlands: Kluwer Academic.

Brascoupé, C. (2002). Rekindling the fire of traditional agriculture. Biodiversity, 3(3), 26. http://dx.doi.org/10.1080/14888386.2002.9712596

Briggs, J., Sharp, J., Yacoub, H., Hamed, N., \& Roe, A. (2007). The nature of indigenous environmental knowledge production: Evidence from Bedouin communities in southern Egypt. Journal of International Development, 19(2), 239-251. http://dx.doi.org/10.1002/jid.1337

Brush, S. B. (2002). Protectors, prospectors, and pirates of biological resources. In L. Maffi (Ed.), On biocultural diversity: Linking language, knowledge, and the environment (pp. 517-532). Washington, D.C.: Smithsonian Institution Scholarly Press.

Brush, S. B. (2007). Farmers' rights and protection of traditional agricultural knowledge. World Development, 35(9), 1499-1514. http://dx.doi.org/10.1016/j.worlddev.2006.05.018

Brush, S. B., \& Stabinsky, D. (1996). Valuing local knowledge: Indigenous people and intellectual property rights. Washington, D.C.: Island Press.

Cardinale, B. J., Duffy, J. E., Gonzalez, A., Hooper, D. U., Perrings, C., Venail, P., . . Naeem, S. (2012). Biodiversity loss and its impact on humanity. Nature, 486(7401), 59-67. http://dx.doi.org/10.1038/nature11148

Cooper, H. D. (2002). The International Treaty on Plant Genetic Resources for Food and Agriculture. Review of European, Comparative \& International Environmental Law, 11(1), 1-16. http://dx.doi.org/10.1111/1467$\underline{9388.00298}$

Correa, C. M. (2003). The access regime and the implementation of the FAO International Treaty on Plant Genetic Resources for Food and Agriculture in the Andean group countries. The Journal of World Intellectual Property, 6(6), 795-806. http://dx.doi.org/10.1111/j.1747-1796.2003. tb00243.x

Coupe, S., \& Lewins, R. (2007). Negotiating the seed treaty. Warwickshire, UK: Practical Action, Schumacher Centre for Technology and Development.

Crosby, A. W. (1972). The Columbian Exchange: Biological and cultural consequences of 1492. Westport, Connecticut: Greenwood.

Deloria, V., Jr. (1995). Red earth, white lies: Native Americans and the myth of scientific fact. New York: Scribner.

Food and Agriculture Organization of the United Nations [FAO]. (2009). International Treaty on Plant Genetic Resources for Food and Agriculture: A global treaty for food security and sustainable agriculture. Rome: Author. Retrieved from ftp://ftp.fao.org/docrep/ $\underline{\mathrm{fao} / 011 / \mathrm{i} 0510 \mathrm{e} / \mathrm{i} 0510 \mathrm{e} . \mathrm{pdf}}$

FAO. (2010). The second report on the state of the world's plant genetic resources for food and agriculture. Rome: Author. Retrieved March 16, 2014, from http://www.fao. org/agriculture/crops/core-themes/theme/seeds$\mathrm{pgr} / \mathrm{sow} / \mathrm{sow} 2 / \mathrm{en} /$

FAO. (2013). The state of food and agriculture 2013: Food systems for better nutrition. Rome: Author. Retrieved from http://www.fao.org/docrep/018/i3300e/ i3300e00.htm

Fedoroff, N. V. (2010). The past, present and future of crop genetic modification. New Biotechnology, 27(5), 461-465. http://dx.doi.org/10.1016/j.nbt.2009.12.004

Fowler, C. (1994). Unnatural selection: Technology, politics, and plant evolution. Yverdon, Switzerland: Gordon and Breach.

Fowler, C. (2008). The Svalbard Global Seed Vault: Securing the future of agriculture. Bonn, Germany: The Global Crop Diversity Trust.

Fowler, C., \& Mooney, P. (1990). The threatened gene: Food, politics, and the loss of genetic diversity. Cambridge, UK: Lutterworth Press.

Fowler, C., Smale, M., \& Gaiji, S. (2001). Unequal exchange? Recent transfers of agricultural resources and their implications for developing countries. Development Policy Review, 19(2), 181-204. http://dx.doi.org/10.1111/1467-7679.00130

Global Crop Diversity Trust [GCDT]. (n.d.). Supporting the global system. Retrieved March 16, 2015, from https://www.croptrust.org/what-we-do/ supporting-the-global-system/ 
Government of Norway. (n.d.). Svalbard Global Seed Vault. Retrieved March 16, 2015, from https://www.regjeringen.no/en/topics/foodfisheries-and-agriculture/agriculture/svalbardglobal-seed-vault/id462220/

Grydehøj, A., Grydehøj, A., \& Ackrén, M. (2012). The globalization of the Arctic: Negotiating sovereignty and building communities in Svalbard, Norway. Island Studies Journal, 7(1), 99-118. http://www.islandstudies.ca/

Harlan, J. R. (1995). The living fields: Our agricultural heritage. Cambridge, UK, and New York: Cambridge University Press.

Helfer, L. R. (2003). Intellectual property rights and the international treaty on plant genetic resources for food and agriculture. American Society of International Law Proceedings, 97, 33-35.

Kastler, G., Onorati, A., \& Brac, B. (2013). Seeds and peasant autonomy. In A. Bellows, C. Callenius, C. Campeau, M. A. Cedeño, M. Immink, K. McNeely,...M. Wolpold-Bosien (Eds.), Right to food and nutrition watch 2013: Alternatives and resistance to policies that generate hunger (pp. 47-53). Heidelberg, Germany: Brot für die Welt, FIAN International, and ICCO Cooperation. Retrieved from http://reliefweb.int/report/world/alternatives-andresistance-policies-generate-hunger

Kloppenburg, J. R., Jr. (2005). First the seed: The political economy of plant biotechnology. Madison: University of Wisconsin Press.

LaDuke, W. (2005). Recovering the sacred: The power of naming and claiming. Cambridge, Massachusetts: South End Press.

LaDuke, W., with Alexander, S. (n.d.). Food is medicine: Recovering traditional foods to beal the people. Minneapolis, Minnesota: Honor the Earth.

Lertzman, D.A. (2010). Best of two worlds: Traditional ecological knowledge and Western science in ecosystem-based management. Journal of Ecosystems and Management, 10(3), 104-126. http://jem.forrex.org/index.php/jem

Mann, C. C. (2011). 1493: Uncovering the new world Columbus created (1st ed.). New York: Knopf.

Martinez, D. (1998). First People-firsthand knowledge. Retrieved July 23, 2014, from http://www.ser. org/docs/default-document-library/first-peoplefirsthand-knowledge.pdf?sfvrsn $=0$
Mascarenhas, M., \& Busch, L. (2006). Seeds of change: Intellectual property rights, genetically modified soybeans and seed saving in the United States. Sociologia Ruralis, 46(2), 122-138. http://dx.doi. org/10.1111/j.1467-9523.2006.00406.x

McIntyre, B. D., Herren, H. R., Wakhungu, J., \& Watson, R. T. (Eds.). (2009). Agriculture at a crossroads: Synthesis report of the International Assessment of Agricultural Knowledge, Science and Technology for Development. Washington, D.C.: Island Press.

Menzies, C. R. (Ed.). (2006). Traditional ecological knowledge and natural resource management. Lincoln, Nebraska: University of Nebraska Press.

Mgbeoji, I. (2006). Global biopiracy: Patents, plants, and indigenous knowledge. Vancouver: UBC Press.

Mt. Pleasant, J. (2011). Traditional Iroquois corn: Its history, cultivation, and use. Ithaca, New York: Natural Resource Agriculture and Engineering Service, Cooperative Extension.

Mushita, A., \& Thompson, C. B. (2007). Biopiracy of biodiversity: Global exchange as enclosure. Trenton, New Jersey: Africa World Press.

Nabhan, G. P. (1997). Cultures of habitat: On nature, culture, and story. Berkeley, California: Counterpoint.

Nabhan, G. P. (2002). Enduring seeds: Native American agriculture and wild plant conservation. Tucson, Arizona: University of Arizona Press.

Nazarea, V. D., Rhoades, R. E., \& Andrews-Swann, J. E. (2013). Seeds of resistance, seeds of hope: Place and agency in the conservation of biodiversity. Tucson, Arizona: University of Arizona Press.

Nelson, M. K. (Ed.). (2008). Original instructions: Indigenous teachings for a sustainable future. Rochester, Vermont: Bear.

O'Flaherty, R. M., Davidson-Hunt, I. J., \& Manseau, M. (2008). Indigenous knowledge and values in planning for sustainable forestry: Pikangikum First Nation and the Whitefeather Forest Initiative. Ecology and Society, 13(1), 6. http://www.ecologyand society.org/vol13/iss1/art6/

Pant, L. P., \& Ramisch, J. J. (2010). Beyond biodiversity: Culture in agricultural biodiversity conservation in the Himalayan foothills. In L. German, J. J. Ramisch, \& R. Verma (Eds.), Beyond the biophysical: Knowledge, culture, and power in agriculture and natural resource management (pp. 73-97). Dordrecht, the Netherlands: Springer. 
Pechlaner, G. (2012). Corporate crops: Biotechnology, agriculture, and the struggle for control. Austin, Texas: University of Texas Press.

Robinson, D. F. (2010). Confronting biopiracy: Challenges, cases and international debates. Washington, D.C.: Earthscan.

Ross, A., Sherman, K. P., Snodgrass, J. G., Delcore, H. D., \& Sherman, R. (2011). Indigenous peoples and the collaborative stewardship of nature: Knowledge binds and institutional conflicts. Walnut Creek, California: Left Coast Press.

Senior, K. (2004). Treaty improves access to plant genetic resources [Dispatches]. Frontiers in Ecology and the Environment, 2(6), 286. http://dx.doi.org/ 10.1890/1540-9295(2004)002[0284:D]2.0.CO;2

Shiffrin, S. V. (2001). Lockean arguments for private intellectual property. In S. R. Munzer (Ed.), New essays in the legal and political theory of property (pp. 138-167). Cambridge, UK: Cambridge University Press.

Shiva, V. (1997). Biopiracy: The plunder of nature and knowledge. Boston: South End Press.
Shiva, V., Lockhart, C., \& Shroff, R. (Eds.). (2013). The law of the seed. Florence, Italy: Navdanya International. Retrieved from http://seedfreedom.info

Shiva, V., Shroff, R., \& Lockhart, C. (Eds.). (2012). Seed freedom: A global citizens' report. New Delhi, India: Navdanya. Retrieved from http://seedfreedom.info

Tully, J. (1980). A discourse on property: John Locke and his adversaries. Cambridge, UK: Cambridge University Press.

Westengen, O. T., Jeppson, S., \& Guarino, L. (2013). Global ex-situ crop diversity conservation and the Svalbard Global Seed Vault: Assessing the current status. PLOS One, 8(5), e64146. http://dx.doi.org/10.1371/journal.pone.0064146

Wilson, E. O. (2002). The future of life (1st ed.). New York: Knopf.

Wilson, G. L. (1987). Buffalo Bird Woman's garden: Agriculture of the Hidatsa Indians. St. Paul, Minnesota: Minnesota Historical Society Press.

Young, I. M. (2011). Justice and the politics of difference. Princeton, New Jersey: Princeton University Press. 